\title{
Strengthening women's tenure rights and participation in community forestry
}

\author{
Concepta Mukasa, Alice Tibazalika, Esther Mwangi, Abwoli Y. Banana, Allan Bomuhangi and Jimmy Bushoborozi
}

\section{Key messages}

- Although women's rights and participation may be granted by statute, they are not automatically exercised or implemented due to cultural norms, lack of capacities or inadequate budgets.

- In the absence of effective implementation of gender equitable statutes, negotiation and facilitation by trusted intermediaries can begin to strengthen women's rights and participation, and lower transaction costs of collective action.

- Adaptive Collaborative Management (ACM), which aims to level the playing field, resolve conflict, foster collaboration and negotiation, and build skills and capacities, is a viable way to promote gender equity, even among communities that are strongly patriarchal and characterized by cultural practices that exclude women from tree planting and land ownership.

- Men are important actors for strengthening women's rights and overall empowerment. Mixed groups of men and women can be viable pathways for women's empowerment as opposed to women's only groups.

- ACM facilitation has opened up opportunities to improve local livelihoods and demonstrated gains to sustainable forest and land management, especially on-farm tree planting and the restoration of degraded forests.

\section{Introduction}

A large and growing body of evidence demonstrates that women's involvement in forest management produces substantial gains for forest conservation and for livelihoods more generally (Agarwal 2010). Despite this, women continue to be shut out of decision making and are often not represented in forestry decision-making bodies. Similarly, benefits from forest and tree resources tend to be allocated disproportionately to men, who often gain from trade in high-value products (Howard and Nabanoga 2007; Rugadya 2010).

In Uganda, there is important progress in gender mainstreaming in the forestry sector. The Forestry Policy, Forestry Act and Forestry Plan all address gender and women's specific needs (Banana et al. 2012; Mukasa et al. 2012). However, implementation is weak and cultural norms, beliefs and practices continue to pose significant constraints to women's access and control over forest and tree resources. This limits their participation in decision making and benefits capture, and undermines their investment in sustainable use and management of forest and tree resources.
This infobrief summarizes the findings of a five-year process (2011-16) that explored how to strengthen women's rights to forests and trees and increase their participation in forest decision making and benefits capture. It presents insights from the implementation of Adaptive Collaborative Management (ACM), an approach tested in different cultural settings. ACM has been found to improve participation of marginalized groups in community forestry processes, including decision making and benefits sharing (Colfer 2005a, 2005b; McDougall et al. 2007; Mandondo et al. 2008; Diaw et al. 2009; Mutimukuru-Maravanyika 2012). In particular, we highlight the governance arrangements, practices and processes that are central to enhancing gender inclusion in community forestry within three districts in Uganda (see Figure 1).

\section{Methodology}

We used ACM to implement interventions chosen by people in six randomly selected communities in four districts in Uganda. ACM is a value-adding approach whereby people with interests in a natural resource agree to act together to plan, observe and learn, 


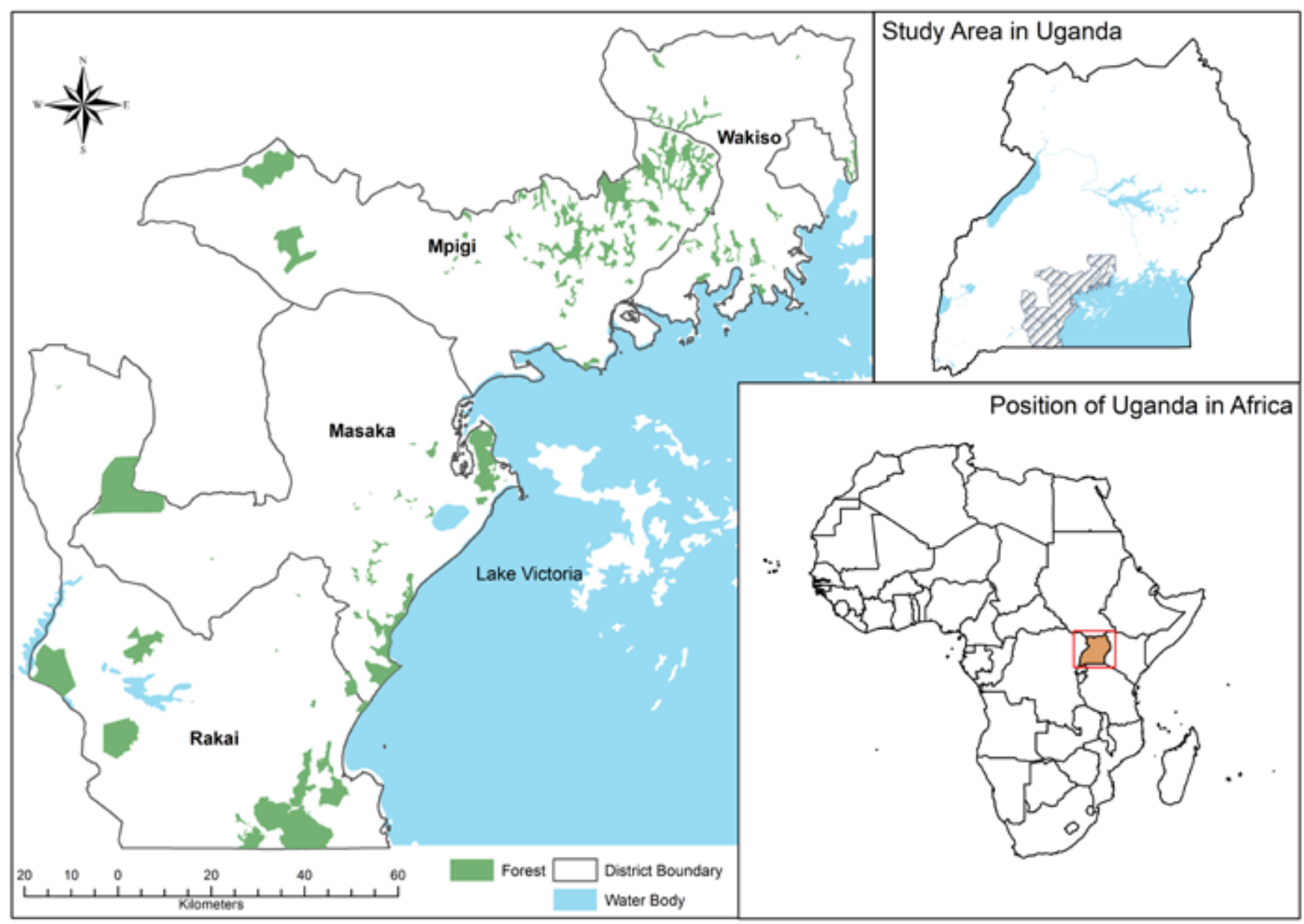

Figure 1. Lake Victoria Crescent covering the study districts of Mpigi, Masaka and Rakai.

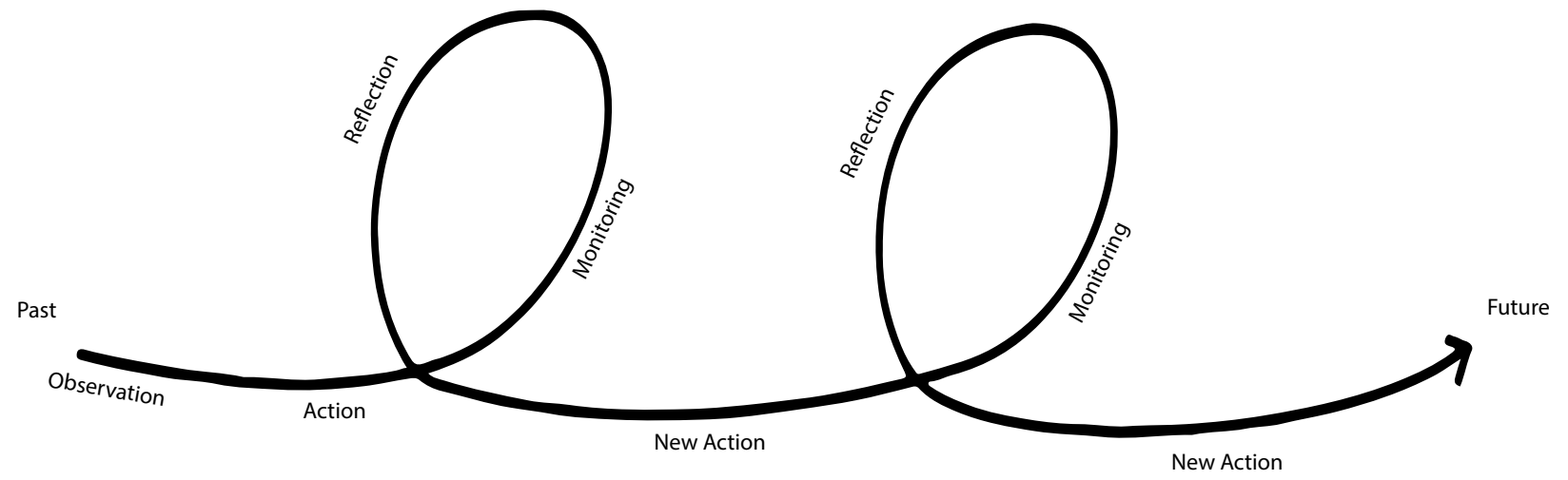

Figure 2. Participatory action research process.

Source: Komarudin et al. 2008. 
recognizing that plans often fail to achieve their stated objectives. It employs a cycle of participatory action research whereby participants jointly identify problems; outline, implement and monitor actions; reflect on what does and doesn't work; and identify further actions to address what is not working (see Figure 2). Such groups consciously communicate, collaborate, negotiate, resolve conflicts and seek out opportunities to learn collectively about the impacts of their actions (CIFOR 2008). The ACM was conducted by facilitators trained in the methodology, including community members based in each of the six study areas.

Participatory methodologies in ACM included visioning and participatory planning, implementation of action plans, indicator development, participatory monitoring and evaluation, trainings, exchange visits, linkage creation, documentation, publication and dissemination of information and policy engagements.

The indicators developed jointly with communities for monitoring and evaluating progress in implementing selected activities, particularly gender equality, included: number of women: a) in leadership positions; b) attending community meetings; c) contributing actively to discussions; d) owning trees on 'their' farms and/or in central forest reserves (CFR); e) controlling incomes/benefits. These indicators represent the existence of key forums (i.e. community meetings) and positions that make major decisions on forest use, management and benefit sharing.

Six ACM groups involving 279 members - 128 men and 151 women - participated voluntarily in the study. At the start of the project, women expressed concerns over several forest and tree-related issues that included the following:

- $\quad$ exclusion from decisions despite their use and management of forests and trees

- absence in leadership positions

- poor attendance at meetings

- lack of confidence to speak up during meetings

- cultural norms that prevent them from planting, owning and economically benefiting from trees.
The ACM process and interventions were aimed at addressing these concerns. Figure 3 below illustrates the ACM framework and the pathway toward transforming gender relations in forest and tree use and management.

\section{Results}

\section{Tree planting}

With facilitation and support from the ACM team, the men allowed women to plant trees on family farms and allocated them portions of the farm for planting trees of their choice. Across all six project sites, up to 51 women planted Ficus, a 'forbidden' tree species that symbolizes land ownership. Two of these women have reported earnings from the sale of barkcloth made from Ficus. In addition, women planted other trees like eucalyptus, pine and Maesopsis spp, which were commonly planted only by men. Overall, women user group members planted 8541 trees of different types (Figure 4). At the start of the ACM work, only 5 women had woodlots with trees ranging from 5-100 trees totaling up to approximately 350 trees
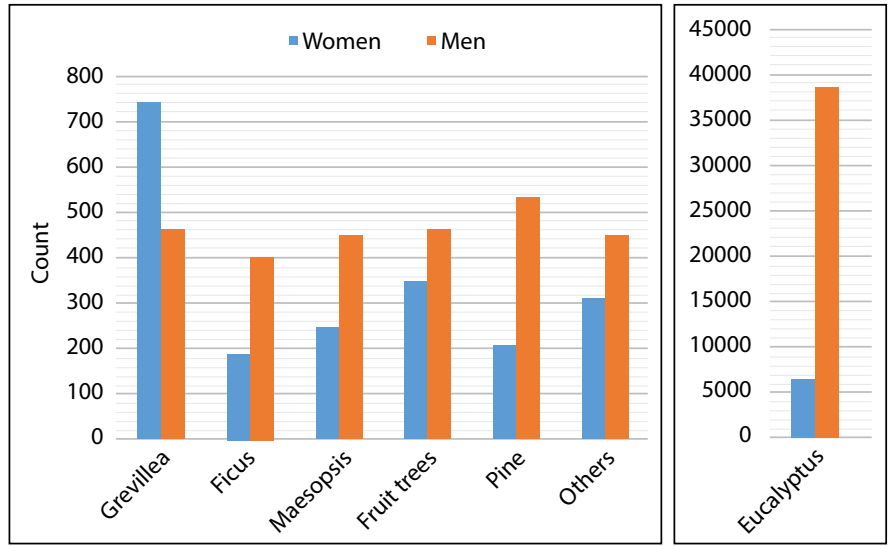

Figure 4. Number of tree species planted by men and women user group members.

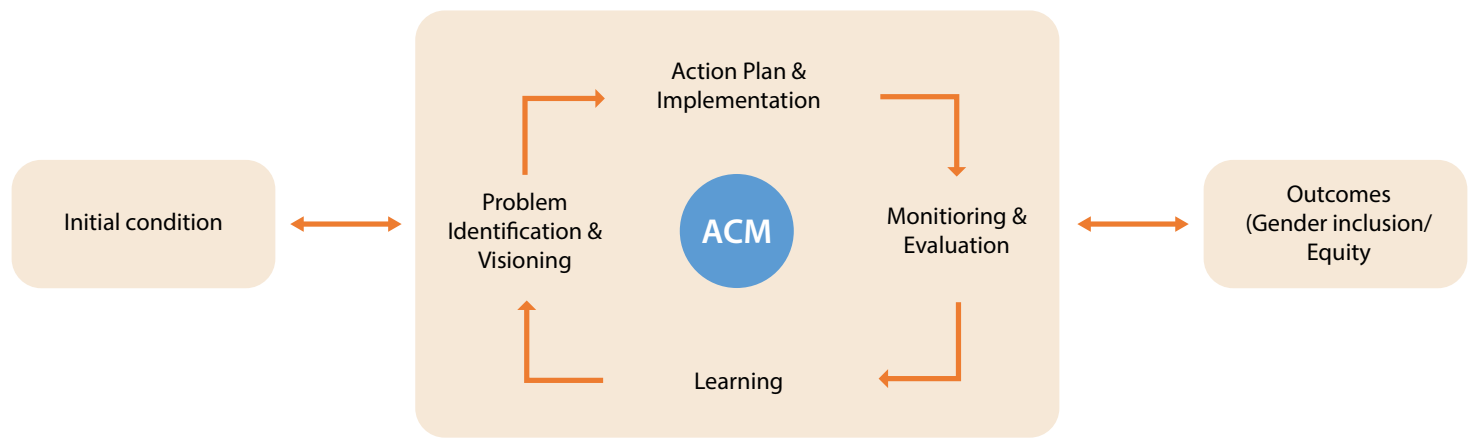

Figure 3. Framework of ACM implementation. 


\section{Women's participation in decision making}

Prior to starting the ACM, there were two groups organized in relation to forest use and management across all six project sites. Both groups only had one woman among nine men in each executive committee. By 2016, the number of executive committee members had risen to 36 women and 31 men (see Table 1). Currently, women chair three of six groups and occupy several other positions within the executive committees. Furthermore, women's participation in group discussions increased to the same level as men; men no longer dominated. As an important spin-off, the number of women from the study sites that vied for political positions in the 2015 elections increased: 18 women vied for political positions - 16 for the first time - and 2 were successful.

Electing women into leadership positions is an important step toward involving them in decision making of the user groups. However, women elected to leadership often delegated their responsibilities to men and were reluctant to initiate contact with or follow-up actions with external actors such as sub-national government officials or nongovernmental organizations (NGOs). Consequently, various capacity building efforts - which also involved men - boosted women's leadership skills and confidence. Training in gender concepts and their application helped build awareness of, and challenge, existing gender norms. Besides leadership training, men and women were trained in skills such as tree seedling nursery development and management, forest management, community forestry rules and regulations, bee keeping and fisheries. Participants identified training needs for skill building, which were then offered by NGO and government officials.
The main features and mechanisms of the ACM process that played an important part in catalyzing change include the following:

- $\quad$ ACM facilitators created a safe space where women could speak up and share their opinions in the presence of men free of intimidation or retribution.

- Capacity building and training helped build the knowledge, skills and confidence of women.

- $\quad$ The process encouraged women to work alongside their husbands and other men so that the benefits of group action were distributed beyond women.

- $\quad$ Promoting alternative livelihoods activities through, for instance, village banking schemes, provided independent income sources for women, as well as an alternative domain for women to transfer their organizational and leadership skills, further entrenching their confidence.

- $\quad$ The development of formal, registered groups provided a legally recognized structure for collective action and for greater security of access to and use of trees and forests. These registered groups opened up avenues for external actors such as the NFA and NGOs to support group activities.

- $\quad$ ACM facilitation helped provide a system for community members to identify problems; determine actions for mitigating problems; troubleshoot; think through gendered implications of actions; suggest and support horizontal and vertical linkages; and, pressure local authorities and officials to be responsive to local community efforts.

Figure 5 on the next page summarizes how the different elements of the ACM process interacted to result in more gender-equitable outcomes in forest and tree use and management in the study sites.

Table 1. Changes in women's leadership and overall participation.

\begin{tabular}{|c|c|c|}
\hline Activity & Before ACM intervention & After ACM intervention \\
\hline \multicolumn{3}{|l|}{ Gender-based } \\
\hline Women in leadership & 2 out of 18 executives (11\%). & 36 of 67 executives. \\
\hline Women planting and owning trees & 5 women had woodlots. & 151 women have planted and own the trees. \\
\hline Planting of Ficus natalensis & $\begin{array}{l}\text { No woman planted Ficus as it } \\
\text { symbolizes land ownership. }\end{array}$ & $\begin{array}{l}51 \text { of } 167 \text { women members have planted Ficus; } \\
2 \text { women have sold barkcloth made from Ficus. }\end{array}$ \\
\hline $\begin{array}{l}\text { Number of trees planted and } \\
\text { owned by women }\end{array}$ & $\begin{array}{l}\text { Approximately } 350 \text { trees, mainly fruit } \\
\text { trees for subsistence. Some women } \\
\text { had never planted a tree before. }\end{array}$ & $\begin{array}{l}\text { Women planted } 8541 \text { trees, mainly eucalyptus, for } \\
\text { both subsistence (firewood) and commercial use. }\end{array}$ \\
\hline Confidence levels & Low participation in group activities. & $\begin{array}{l}\text { Attendance in group activities is relatively higher for } \\
\text { women; average attendance is } 13 \text { women and } 11 \text { men. }\end{array}$ \\
\hline Contribution to discussions & $\begin{array}{l}\text { Men and male youth dominated } \\
\text { discussions. }\end{array}$ & $\begin{array}{l}\text { Almost at 1:1; women and men contribute equally to } \\
\text { discussions. }\end{array}$ \\
\hline Involvement in political leadership & 2 were elected as political leaders. & 18 vied for political leadership (16 for their first time). \\
\hline $\begin{array}{l}\text { Trees planted and owned in Central } \\
\text { forest reserves }\end{array}$ & None. & $\begin{array}{l}\text { About } 26,600 \text { of } 49,911 \text { trees planted in CFR were } \\
\text { planted by both men and women. }\end{array}$ \\
\hline
\end{tabular}




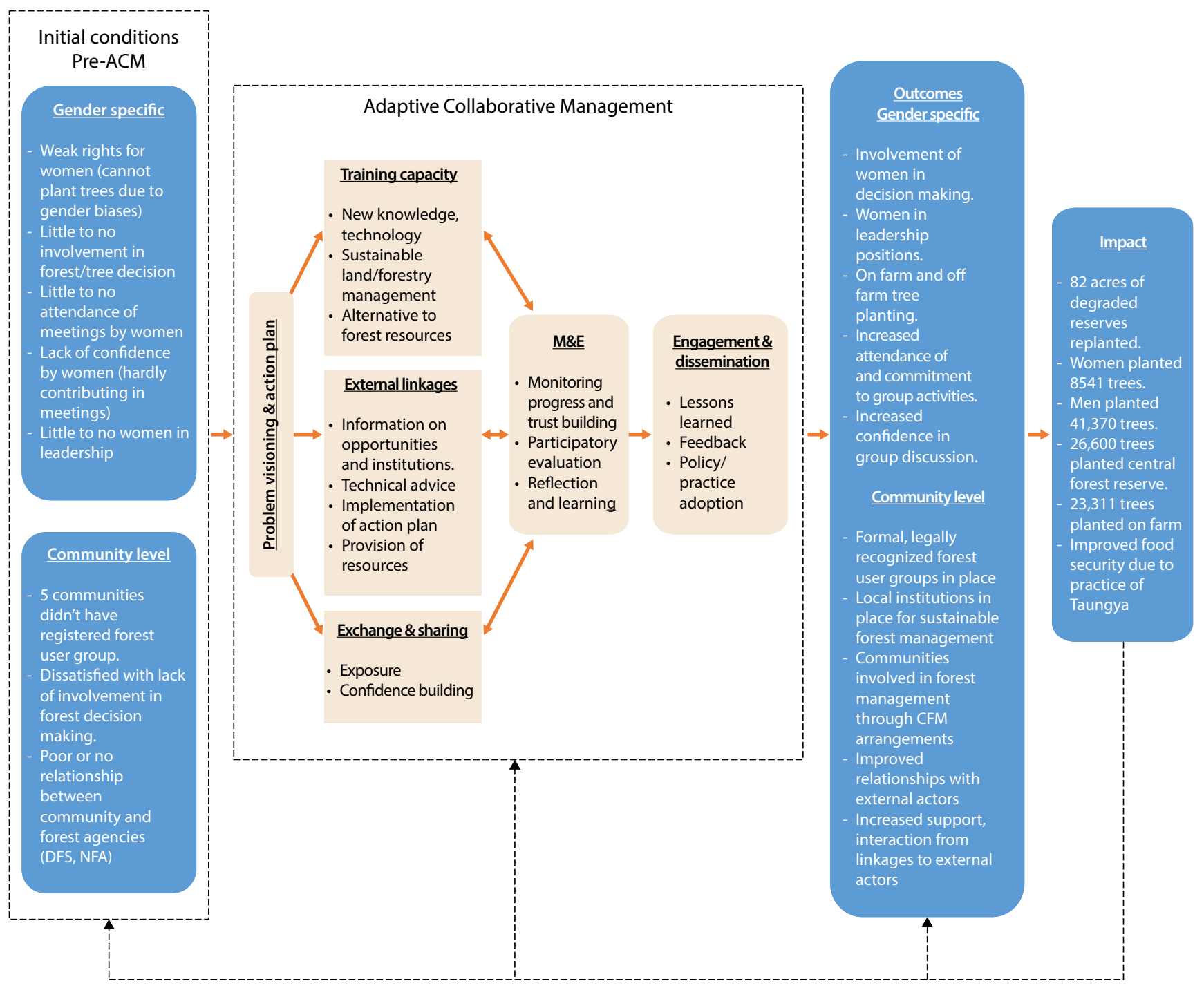

Figure 5. The ACM process and gender equitable outcomes.

\section{Conclusion}

In Uganda, though the Forest Act and Forest Policy are explicit about securing the tenure rights of women and ensuring their participation in decision making and benefits, implementation of these goals falls short of the vision. Our work was intended to address this gap in implementation at the grassroots level by identifying ways to strengthen women's rights and enhance their participation in decision making. After close to six years of ACM implementation in six field sites, involving 110 men and 173 women, the approach has resulted in solid gains for gender equality in forest use and management, strengthening women's rights to forests and trees, and bringing them to the center of decision making and leadership in local forestry. However, ACM is a time- and resource-intensive process and community-identified activities require regular meetings, as well as a modest injection of capital. 
Vi Agroforestry, Tree Talk, Narozari Catholic Mission, Rubaga Rotary club, Mpigi District Farmers Association (MPIFA), Mr. Sekyeewa a private tree farmer and Kigazi Tukwatirewamu Collaborative Forestry Management group. Our heartfelt gratitude go to all the user group members (men and women) in the six sites who worked tirelessly to implement the ACM.

\section{References}

Agarwal B. 2010. Gender and Green Governance: The Political Economy of Women's Presence Within and Beyond Community Forestry. Oxford: Oxford University Press. 51323d8a-ca37-4456-9e9e-799ef744b6a6.

Banana AY, Bukenya M, Arinaitwe E, Birabwa B and Sekindi S. 2012. Gender, tenure and community forests in Uganda. Working Paper, No. 87. Bogor, Indonesia: CIFOR.

[CIFOR] Center for International Forestry Research. 2008. Adaptive collaborative management can help us cope with climate change. infobrief No. 13, July. Bogor, Indonesia: CIFOR.

Colfer CJP, ed. 2005a. The Equitable Forest: Diversity, Community and Resource Management. Washington, DC: Resources for the Future.

Colfer CJP 2005b. The Complex Forest: Communities, Uncertainty and Adaptive Collaborative Management. Washington, DC: Resources for the Future.

Diaw MC, Aseh T and Prabhu R., eds. 2009. In Search of Common Ground. Adaptive Collaborative Management in Cameroon. Bogor, Indonesia: CIFOR.

Howard PL and Nabanoga G. 2007. Are there customary rights to plants? An inquiry among the Baganda
(Uganda) with special attention to gender. World Development 35(9):1542-1563.

Komarudin H, Siagian Y and Colfer CJP. 2008. Collective action to secure property rights for the poor: A case study in Jambi Province, Indonesia. Collective Action and Property Rights (CAPRi). Working Paper No. 90. Washington, DC: International Food Policy Research Institute.

McDougall C, Ojha H, Pandey RK, Banjade MR and Pandit PH. 2007. Enhancing adaptiveness and collaboration in community forestry in Nepal: Reflections from participatory action research. In Fisher R, Prabhu R, McDougall C, eds. Adaptive Collaborative Management of Community Forests in Asia. Bogor, Indonesia: CIFOR. pp. 52-92.

Mukasa C, Tibazalika A, Mango A and Muloki MN. 2012. Gender and forestry in Uganda: Policy, legal and institutional frameworks. Working Paper No. 89. Bogor, Indonesia: CIFOR.

Mandondo A, Prabhu R and Matose F, eds. 2008. Coping Amidst Chaos: Studies on Adaptive Collaborative Management from Zimbabwe. Bogor, Indonesia: CIFOR.

Rugadya M. 2010. Women's Land Rights in Uganda: Status of Implementation of Policy and Law on Women's Land Rights for ECA. Addis Ababa: African Centre for Gender Studies and Maastricht University.

Mutimukuru-Maravanyika T. 2012. Can we learn our way to sustainable forest management? Adaptive collaborative management in Mafungautsi State Forest, Zimbabwe [PhD Thesis]. Wageningen: Wageningen University and Research Centre.

\begin{tabular}{|c|c|c|}
\hline CGIAR & $\begin{array}{l}\text { RESEARCH } \\
\text { PROGRAM ON } \\
\text { Forests, Trees and } \\
\text { Agroforestry }\end{array}$ & $\begin{array}{l}\text { This research was carried out by CIFOR as part of the CGIAR Research Program on Forests, Trees and } \\
\text { Agroforestry (CRP-FTA). This collaborative program aims to enhance the management and use of } \\
\text { forests, agroforestry and tree genetic resources across the landscape from forests to farms. CIFOR } \\
\text { leads CRP-FTA in partnership with Bioversity International, CATIE, CIRAD, the International Center for } \\
\text { Tropical Agriculture and the World Agroforestry Centre. }\end{array}$ \\
\hline
\end{tabular}

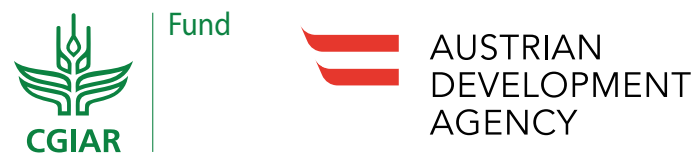

